\title{
Original
}

\section{Estrogen synthesis in the stomach of Sprague-Dawley rats: comparison to Wistar rats}

\author{
Hiroto KOBAYASHI ${ }^{1)}$, Nobuyuki SHIRASAWA ${ }^{2)}$ and Akira NAITO ${ }^{1)}$ \\ 1) Department of Anatomy and Structural Science, Faculty of Medicine, Yamagata University, 2-2-2 Iida-nishi, Yamagata \\ 990-9585, Japan \\ 2) Department of Rehabilitation, Faculty of Medical Science and Welfare, Tohoku Bunka Gakuen University, Aoba-ku, Sendai, \\ Miyagi 980-8579, Japan
}

\begin{abstract}
Aromatase, an estrogen synthase, exists in the gastric parietal cells of Wistar rats. The stomach synthesizes large amounts of estrogens and secretes them into the portal vein. We have been particularly studying gastric estrogen synthesis using Wistar rats. However, estrogen synthesis in the stomach of Sprague-Dawley (SD) rats, which are used as frequently as those of the Wistar strain, has not been clarified. We examined steroid synthesis in the stomach of SD rats using immunohistochemistry, in situ hybridization, Western blotting, real-time $\mathrm{PCR}$, and LC-MS/MS. Aromatase also exists in the stomach of SD rats. Its distribution was not found to be different from that of Wistar rats. Results show that $\mathrm{H}^{+} / \mathrm{K}^{+}$-ATPase $\beta$-subunit and aromatase colocalized in double immunofluorescence staining. Each steroid synthase downstream from progesterone was present in the gastric mucosa. These results suggest that steroid hormones are synthesized in the parietal cells in the same pathway as Wistar rats. Although mRNA expression of steroid synthases were higher in SD, no significant difference was found in the amount of protein and each steroid hormone level in the portal vein. Although differences between strains might exist in steroid hormone synthesis, results show that SD rats are as useful as Wistar rats for gastric estrogen synthesis experimentation.
\end{abstract}

Key words: $17 \beta$-estradiol, aromatase, parietal cells, stomach

\section{Introduction}

In Wistar rats, estrogens, which are constituted by estrone (E1), 17ß-estradiol (E2), and estriol (E3), are converted respectively from cholesterol via progesterone, 17 $\alpha$-hydroxyprogesterone, androstenedione, and testosterone by cytochrome P450scc, 17 $\alpha$-hydroxylase (EC: 1.14.14.32), 17ß-hydroxysteroid dehydrogenase (HSD) type 1 or 3 (EC: 1.1.1.62 or 1.1.1.64), and aromatase (EC: 1.14.14.1) in the ovary. In addition to granulosa cells in the ovary, earlier studies have described that seminiferous tubules in the testis and zona reticularis in the adrenal cortex have aromatase and that they synthesize estrogens in small amounts [1-6]. About two decades ago, parietal cells in the stomach of the rats were found to have aromatase. The amount and activity of aromatase in the stomach are comparable to those in the ovary [7, 8]. Furthermore, progesterone, androstenedione, and testosterone in the artery are reportedly present in higher concentrations than in the portal vein, whereas E1 and E2 in portal vein are higher than arterial ones. Therefore, parietal cells have each steroid synthase to convert estrogens from progesterone. They secrete large amounts of E2 into the portal vein. Actually, E2 secreted from the stomach bound to hepatic ER $\alpha$ is metabolized in the liver. It almost does not flow into systemic circulation [7]. Therefore, it is considered that large amounts of E2 from the stomach are involved in maintaining liver functions.

Estrogen synthesis in the parietal cells is not a phe- 
nomenon limited to Wistar rats. Reports describe similar phenomena in goats [9] and humans [10]. Especially, results show that estrogen synthesis in the parietal cells of humans occurs irrespective of age or sex. In humans, symptoms suggesting excessive estrogens such as gynecomastia, testicular atrophy, and emmeniopathy are known to be recognized often in patients with liver dysfunction [11]. These symptoms are known to be associated with the decline of estrogen metabolism in the liver. We also experimentally demonstrated the increment of E2 in systemic circulation in hepatic disease model animals [12-14]. Probably, E2 secreted from the stomach into the portal vein flowed into systemic circulation because of reduction of estrogen metabolism associated with liver damage. We expect that estrogen synthesis in the stomach contributes not only to the gastro-hepatic axis, but also to the endocrine system in the body. Nevertheless, many points remain unclear in the mechanism or regulation of estrogen synthesis in the stomach.

However, the SD rat strain is widely used for studying the endocrine system in the mammary gland [15-22], uterus and vagina [23-27], and pituitary gland [18, 25, 27]. In fact, SD rats are also used widely for safety evaluations, drug evaluations, and various studies because they are easily tamed, have good growth, smaller size, and a higher survival rate in long-term breeding experiments, similarly to Wistar rats. Therefore, SD rats are also used widely for experimental studies to evaluate relation between $\mathrm{E} 2$ and endocrine-related tumors. Nevertheless, nothing is known of gastric estrogens in SD rats as observed in Wistar rats. This study investigated estrogen synthesis in the SD rat stomach; then results were compared with those found for Wistar rats.

\section{Materials and Methods}

\section{Animals}

This study examined 14 intact, Wistar (Slc:Wistar, $\mathrm{n}=7$ ) and SD (Slc:SD, n=7) male rats aged 10 weeks (Japan SLC, Inc., Shizuoka, Japan): Wistar body weight, 210-220 g; SD body weight, $330-340 \mathrm{~g}$. All animals were maintained in a room with a $12 \mathrm{~h}$ light and $12 \mathrm{~h}$ dark cycle (lights on from 7 a.m. to 7 p.m.). They were housed in air-conditioned quarters. The rats were given a standard pellet diet (Oriental Yeast Co., Ltd., Tokyo, Japan) and tap water ad libitum. Before the experiment, they stayed in the room for one week. Rats were anesthetized with mixed anesthetic agents of three types (medetomidine hydrochloride, $0.15 \mathrm{mg} / \mathrm{kg}$ body weight; Nippon Zenyaku Kogyo Co., Ltd., Fukushima, Japan/midazolam, $2 \mathrm{mg} / \mathrm{kg}$ body weight; Astellas Pharma Inc., Tokyo, Ja- pan/ butorphanol tartrate, $2.5 \mathrm{mg} / \mathrm{kg}$ body weight; Meiji Seika Pharma Co., Ltd., Tokyo, Japan). Blood was taken from the portal vein and the abdominal artery. Serum samples were stored at $-30^{\circ} \mathrm{C}$ until steroid hormone levels determined. All animals were killed by exsanguination. The gastric mucosa was then quickly excised and retained at $-80^{\circ} \mathrm{C}$ until assay. All procedures were done at $8 \mathrm{a}$.m. All were performed in accordance with institutional guidelines, and were approved by the animal research ethical committee of Yamagata University.

\section{Histochemistry}

For immunohistochemical and hematoxylin and eosin (HE) staining, the stomach, testis and adrenal gland tissues were fixed overnight at $4^{\circ} \mathrm{C}$ in Bouin's solution without acetic acid. Tissues were then dehydrated in a graded ethanol series, and were embedded in embedding media (Paraplast; Sigma-Aldrich Japan K.K., Tokyo, Japan). The sections were immunostained with the peroxidase-labeled antibody method using antibody against aromatase (1:10,000 for light microscopic analysis, \#MCA2077S; AbD Serotec, Oxford, UK, and 1:1,000 for fluorescence microscopic analysis, \#GTX18995; GeneTex, Inc., Irvine, CA, USA) and $\mathrm{H}^{+} /$ $\mathrm{K}^{+}$-ATPase $\beta$-subunit $(1: 100,000$, \#SM5117; OriGene Technologies Inc., Rockville, MD, USA). Sections were incubated overnight at $37^{\circ} \mathrm{C}$ with the first antibody. Then they were reacted for an hour at $37^{\circ} \mathrm{C}$ with the antimouse and rabbit IgG conjugated with horseradish peroxidase for light microscopic analysis (1:10, Histofine, Simple Stain MAX-PO [MULTI]; Nichirei Corp., Tokyo, Japan). They were developed using $0.002 \%$ 3,3'-diaminobenzidine tetrachloride, $1 \mathrm{mM}$ ammonium nickel (II) sulfate hexahydrate, and $1 \% \mathrm{H}_{2} \mathrm{O}_{2}$ in $20 \mathrm{mM}$ Tris buffer (pH 7.4) as a chromogen. For double staining, the secondary antibody, anti-mouse IgG $(\mathrm{H}+\mathrm{L})$ highly CrossAdsorbed Secondary Antibody Alexa Fluor 568 (red, 1:400, \#A-11031; Thermo Fisher Scientific Inc., Waltham, MA, USA), anti-rabbit IgG $(\mathrm{H}+\mathrm{L})$ highly Cross-Adsorbed Secondary Antibody Alexa Fluor 488 (green, 1:400, \#A-11034; Thermo Fisher Scientific Inc.) and DAPI FluoroPure grade (1:1,000, \#D21490; Thermo Fisher Scientific Inc.), were used for an hour at $37^{\circ} \mathrm{C}$. As a negative control, nearly adjacent sections were incubated without the primary antibody. Then they were incubated with the secondary antibody. No labeling was confirmed in these control sections. The images were taken using a camera (DFC7000T; Leica Microsystems $\mathrm{GmbH}$, Wetzlar, Germany) attached to a microscope (DM2500LED; Leica) and a confocal laser scanning microscope (PASCAL; Carl Zeiss Microscopy GmbH, Jena, Germany). 


\section{In situ hybridization}

The following DNA fragments were amplified from rat cDNA using the polymerase chain reaction $(\mathrm{PCR})$ : Cyp19a1 (GenBank accession no. NM017085; 18242309) with forward (5'- CGA GTA TTT CCC CAA GCC CA-3') and reverse (5'-TTC TTT TGC ATC CCG GCT CT-3') primers. Gene-specific antisense or sense digoxigenin (DIG)-labeled cRNA probes were made using the Roche DIG RNA labeling kit (Roche Diagnostics Corp., Penzberg, Germany). Gastric frozen sections (20 $\mu \mathrm{m}$ thick) were obtained in a cryostat (CM3000; Leica, New York, NY, USA) and were mounted on glass slides with Tissue-Tek O.C.T. Compound (Sakura Finetek Japan Co., Ltd., Tokyo, Japan). Then DIG-labeled cRNA probe hybridization was performed in a solution containing $50 \%$ formamide, $10 \%$ dextran sulfate (Wako Pure Chemical Industries Ltd., Osaka, Japan), $3 \times$ standard sodium citrate, $120 \mathrm{mM}$ phosphate buffer (pH 7.4), $1 \times$ Denhardt solution (Nacalai Tesque Inc., Kyoto, Japan), $125 \mu \mathrm{g} / \mathrm{ml}$ tRNA (Thermo Fisher Scientific Inc.), and $100 \mu \mathrm{g} / \mathrm{ml}$ sonicated sperm DNA (Thermo Fisher Scientific Inc.) at $60^{\circ} \mathrm{C}$ for $16-18 \mathrm{~h}$. Visualization of mRNA was performed with alkaline-phosphatase-conjugated anti-DIG antibody (Roche Diagnostics Corp.) using 4-nitroblue tetrazolium chloride and 5-bromo-4-chloro-3-indolyl phosphate (Roche Diagnostics Corp.). Control experiments were performed. No specific signals were detected in sections processed with DIG-labeled sense RNA probes.

\section{Total RNA extraction and real-time PCR}

Total RNAs were prepared from the gastric mucosa $(n=4)$ by TRIzol RNA isolation reagents (Thermo Fisher Scientific Inc.). Expression of steroid synthesizing enzyme mRNAs in the stomach was determined using real-time PCR. Total RNA was converted into cDNA by reverse transcription using ReverTra Ace qPCR RT Master Mix (Toyobo Co., Ltd., Osaka, Japan). All primers were designed in the laboratory following sequences based on the nucleotide sequences of the rat, and were intron-spanning. The nomenclature of cytochrome P450 genes were used according to the report [28]. Primer sequences are shown in Table 1. Real-time PCR was performed in the StepOnePlus Real-Time PCR System with a Thunderbird SYBR qPCR Mix (Toyobo Co., Ltd.) according to the manufacturer's protocol. PCR conditions were $10 \mathrm{~min}$ at $95^{\circ} \mathrm{C}$, with 40 cycles of denaturation for $15 \mathrm{~s}$ at $95^{\circ} \mathrm{C}$, and an annealing-extension for $60 \mathrm{~s}$ at $60^{\circ} \mathrm{C}$. According to the computational method of Livak $\&$ Schmitten [29], a relative amount of each gene in each animal including $A c t b$ was calculated based on threshold cycles and was compared with that found in the controls. To confirm the absence of contamination of genomic DNA in all RNAs, PCR was conducted without the RT step. None of the total RNAs was able to detect PCR products of either primer set within 40 PCR cycles.

\section{Western blotting}

The gastric mucosa was homogenized in a lysis buffer containing a protease inhibitor (cOmplete ${ }^{\mathrm{TM}}$ Protease Inhibitor Cocktail, Roche Diagnostics Corp.). The protein concentration was estimated (TaKaRa BCA Protein Assay; Takara Bio Inc., Shiga, Japan). For immunoblotting, $10-30 \mu \mathrm{g}$ of total protein was separated on $10 \%$ SDS-PAGE. Protein samples were transferred onto PVDF membranes, blocked with $4 \%$ non-fat dry milk in TBST, and incubated with the primary antibody against 17 $\alpha$-hydroxylase (1:10,000, \#ab231794; Abcam plc., Cambridge, UK), 17 $\beta$-hydroxysteroid dehydrogenase (HSD) type2 (1:10,000, \#GTX12311; GeneTex, Inc.), 17 $\beta$-HSD type3 $(1: 100,000$, \#GTX114480; GeneTex, Inc.), aromatase (1:10,000; AbD Serotec), $5 \alpha$-reductase type 1 (1:3,000, \#bs-11308R; Bioss, Boston, MA, USA), and $\beta$-actin (1:100,000, \#sc-47778; Santa Cruz Biotechnology, Inc., Dallas, TX, USA). Following reaction with

Table 1. List of oligonucleotide primers for real-time PCR

\begin{tabular}{llcc}
\hline \multicolumn{1}{c}{ Gene } & \multicolumn{1}{c}{ Sequence } & Product (bp) & Accession \\
\hline \multirow{2}{*}{ Cyp17al } & $\begin{array}{l}\text { Forward: AGTGATCATCGGCCACTATC } \\
\text { Reverse: GAGCTACCAGCATCTGCAAA }\end{array}$ & 150 & NM_012753 \\
\hline Hsd17b2 & $\begin{array}{l}\text { Forward: TGGTTAACGTCAGCAGCATG } \\
\text { Reverse: ATGGTCACGACTTTGACTCC }\end{array}$ & 139 & NM_024391 \\
\hline Hsd17b3 & $\begin{array}{l}\text { Forward: AGAGTGTCATCCACTGCAAC } \\
\text { Reverse: AGTACAGGCTATACAGAGGC }\end{array}$ & 144 & NM_054007 \\
\hline \multirow{2}{*}{ Cyp19a1 } & $\begin{array}{l}\text { Forward: ATTGGCATGCACGAGAATGG } \\
\text { Reverse: TGCTGCTTGATGGATTCCAC }\end{array}$ & 140 & NM_017085 \\
\hline \multirow{2}{*}{ Srd5a1 } & $\begin{array}{l}\text { Forward: TCAGACCACATCCTGAGGAA } \\
\text { Reverse: TGCAAAGCCACACCACTCCA }\end{array}$ & 129 & NM_017070 \\
\hline \multirow{2}{*}{ Actb } & $\begin{array}{l}\text { Forward: TGACAGGATGCAGAAGGAGA } \\
\text { Reverse: TAGAGCCACCAATCCACACA }\end{array}$ & 114 & NM_031144 \\
\hline
\end{tabular}


anti-mouse or rabbit IgG, HRP-linked antibody (1:3,000, \#7074 or \#7076; Cell Signaling Technology, Inc., Danvers, MA, USA), blots were revealed with ImmunoStar LD (Wako Pure Chemical Industries Ltd.).

\section{Serum steroid hormone concentrations}

Serum steroid hormone concentrations $(\mathrm{n}=7$, each group) were measured using liquid chromatograph-mass spectrometry (LC-MS/MS). As internal standards, progesterone $-{ }^{13} \mathrm{C}_{3}$, androstenedione $-{ }^{13} \mathrm{C}_{3}$, testosterone $-{ }^{13} \mathrm{C}_{3}$, dihydrotestosterone- ${ }^{13} \mathrm{C}_{3}, \mathrm{E} 1-{ }^{13} \mathrm{C}_{4}$, and E2 $-{ }^{13} \mathrm{C}_{4}$ were added to the rat serum. Steroids were extracted using methyl tert-butyl ether from the rat serum. After the organic layer was evaporated to dryness, the extract was dissolved in methanol and was diluted with distilled water. It was then applied to an Oasis MAX cartridge. After the cartridge was washed with $1 \%$ acetic acid solution, $20 \%$ acetonitrile solution, and $1 \mathrm{M}$ sodium hydroxide solution and distilled water, respectively, and A-dione, T, DHT and P4 were eluted with methanol. Furthermore, the cartridge was washed with methanol, $1 \%$ acetic acid solution, methanol/distilled water/pyridine $(60: 40: 1, \mathrm{v} / \mathrm{v} / \mathrm{v})$; the E1 and E2 were eluted with methanol/distilled water/pyridine (90:10:1, v/v/v). After each steroid fraction was evaporated, the fraction of E1 and E2 was subjected to derivatization as described in an earlier report [30]. The fraction of A-dione, T, DHT, and $\mathrm{P} 4$ was subjected to derivatization as described in an earlier report [31]. The lower limits of quantitation of E1, E2, A-dione, T, DHT and P4 were, respectively, $0.05,0.005,2,1,1$, and $2 \mathrm{pg} /$ tube.

\section{Statistical analysis}

The data were analyzed statistically using MannWhitney U test, using StatView software (Hulinks Inc., Tokyo, Japan). A $P$-value less than 0.05 was considered to be significant.

\section{Results}

\section{Aromatase distribution}

Light micrographs of immunostained sections with aromatase antibody are shown in Fig. 1. Distribution of aromatase in the stomach of Wistar rats was confined to corpus as reported earlier (Figs. 1B and C). Aromatase was also expressed weakly in lesser curvature. The frontal stomach of SD rats showed an almost identical structure to that of Wistar rats (Figs. 1D and E). However, no aromatase expression was found in the lesser curvature because the boundary between gastric corpus and fundus (fore-stomach) continues as a borderline to the pylorus. Aromatase does not exist in that location. In sagittal sections, aromatase was not expressed in the fundus (fore-stomach) and pylorus in both Wistar (Figs. $1 \mathrm{G}$ and $\mathrm{H}$ ) and SD rats (Figs. 1I and J). It was observed that aromatase was only expressed in corpus, where the fundic glands exist. Because the borderline in the stomach is not straight, the fundus (fore-stomach) and corpus are mixed in one section. Therefore, aromatase expression in the second from the right section appeared to be interrupted. No aromatase expression was found in the esophagus or duodenum in any micrograph. These results support those of earlier studies.

Because aromatase in the gastric mucosa is well known to exist in parietal cells, double staining of $\mathrm{H}^{+} /$ $\mathrm{K}^{+}$-ATPase $\beta$-subunit and aromatase was performed (Fig. 2). Aromatase in $\mathrm{SD}$ rats colocalized with $\mathrm{H}^{+} / \mathrm{K}^{+}$-ATPase $\beta$-subunit (Figs. 2D-F) and in Wistar rats (Figs. 2A-C). Furthermore, in situ hybridization demonstrated the expression of aromatase mRNA in gastric mucosa in both strains (Fig. 3). In conclusion, results clarified that aromatase exists in the gastric mucosa of corpus of SD rats and that it produces estrogens in parietal cells as well as Wistar rats.

Immunohistochemical analyses with aromatase antibody were also performed for the testis and the adrenal gland, which are known as the main estrogen producing organs in males. Light micrographs of HE (Figs. 4A, C, and $\mathrm{E}$ ) and immunohistochemical staining with aromatase antibody (Figs. 4B, D, and F) of the stomach (Figs. 4A and B), testis (Figs. 4C and D), and adrenal gland (Figs. 4E and F) of SD rats are shown. Testis and adrenal gland tissues did not show aromatase positive cells in the same condition with immunohistochemistry of gastric mucosa.

\section{Steroid synthases in the gastric mucosa}

Gastric $E_{2}$ was synthesized from progesterone via androstenedione and testosterone by steroidogenic enzymes, 17 $\alpha$-hydroxylase, 17 $\beta$-HSD type2, 17 $\beta$-HSD type 3 and aromatase, in the mucosal layer. Furthermore, $5 \alpha$-reductase type1, which converts testosterone to dihydrotestosterone, exists. Consequently, expressions of these mRNAs, Cyp17a1, Hsd17b2, Hsd17b3, Cyp19a1, and $\operatorname{Srd5a1}$, were determined using real-time PCR. The results, normalized by $A c t b$ expression, are presented in Fig. 5. Cyp 17 a 1 mRNA expression in the gastric mucosal epithelium of SD rats was about 1.4 fold, $H s d 17 b 3$ was about 1.5 fold, Cyp19al was about 2.1 fold, and Srd5al was about 4.1 fold higher than that of Wistar rats $(P<0.05$, respectively). Also, $H s d 17 b 2$ mRNA expression was lower: about 0.8 fold $(P<0.05)$. However, steroid synthase proteins in mucosal epithelia of the stomach were analyzed using Western blotting in Fig. 6. Lysates 


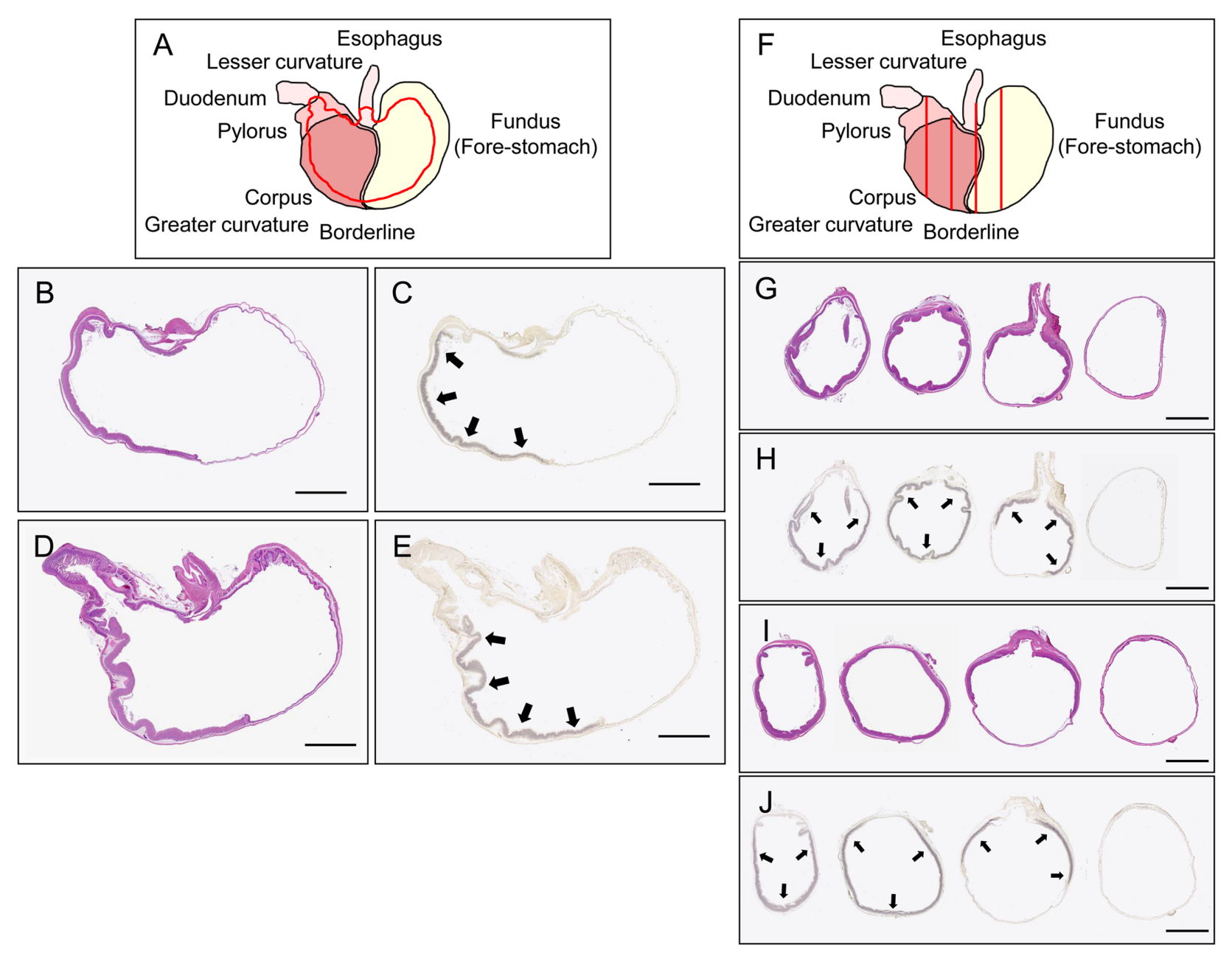

Fig. 1. Schema (A and F) and light photomicrographs showing conventional HE staining and aromatase immunohistochemistry in frontal and sagittal stomachs of Wistar (B, C, G, and H) and SD (D, E, I and J) rats are shown. Red lines in schemas show crosssections. Aromatase-positive cells (arrows) were observed only in the gastric corpus as dark purple. Scale bars represent $5 \mathrm{~mm}$.

of gastric mucosa were loaded on SDS-PAGE. Each synthase and $\beta$-actin were detected by immunoblotting. All steroid synthases were confirmed in SD rats. Results of image analysis of Wistar vs. SD shown in mean $\pm \mathrm{SE}$ were $17 \alpha$-hydroxylase; $2.68 \pm 0.35$ vs. $2.52 \pm 0.11$ $(P=0.5127), 17 \beta-H S D$ type $2 ; 0.78 \pm 0.01$ vs. $0.84 \pm 0.16$ $(P=0.5127), 17 \beta$-HSD type $3 ; 0.93 \pm 0.06$ vs. $1.17 \pm 0.06$ $(P=0.1266)$, aromatase; $1.35 \pm 0.08$ vs. $1.51 \pm 0.05$ $(P=0.1266)$, and $5 \alpha$-reductase type $1 ; 0.89 \pm 0.05$ vs. 0.91 $\pm 0.06(P=0.8273)$. Then, no significant difference was found between Wistar and SD rats in any steroid synthase.

\section{Serum steroid hormone concentrations in the portal vein}

Table 2 shows each steroid hormone concentration in the portal vein. Progesterone, a substrate of gastric estrogens, was not different between Wistar and SD rats $(P=0.631)$. Although no significant difference was found in androstenedione, which is converted from progester- one by $17 \alpha$-hydroxylase, androstenedione in SD rats tended to be higher $(P=0.583)$. Similarly to androstenedione, testosterone, which is converted from androstenedione by $17 \beta-H S D$ type 3 and dihydrotestosterone, which is converted from testosterone by $5 \alpha$-reductase type 1 tended to be higher in $\mathrm{SD}$ rats $(P=0.1495,0.4233$ respectively). No significant difference was found in estrone converted from androstenedione by aromatase $(P=0.5224)$. Furthermore, $17 \beta$-estradiol converted from testosterone by aromatase was not significantly different. However, $17 \beta$-estradiol in SD rats tended to be lower $(P=0.1495)$.

\section{Discussion}

Results of this study clarified that SD rats also synthesize estrogens in the stomach similarly to Wistar rats. The distribution of aromatase in the stomach of SD rats is identical to that in Wistar rats (Figs. 1 and 2). Furthermore, not only aromatase protein but also mRNA is 

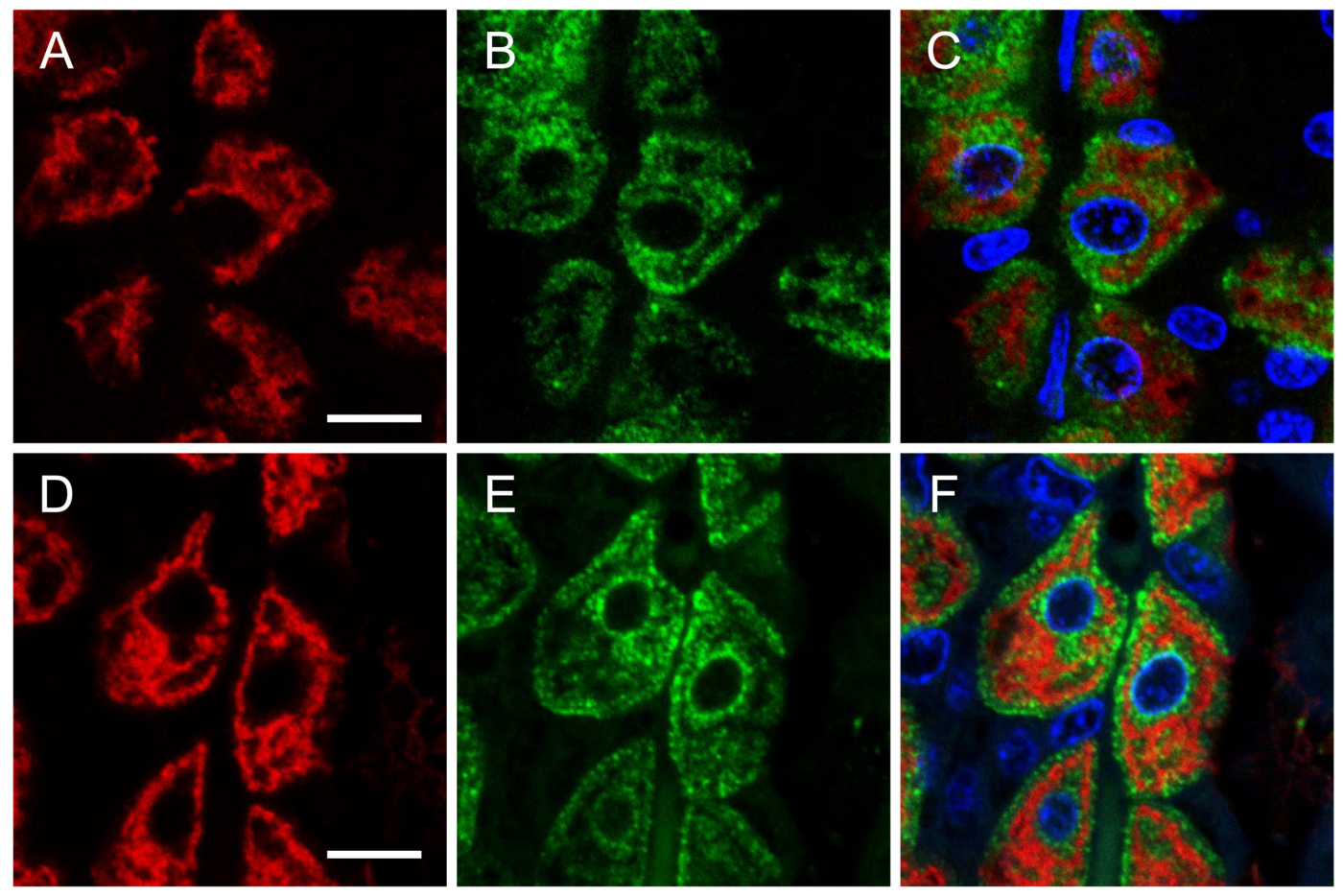

Fig. 2. Immunofluorescence staining for $\mathrm{H}^{+} / \mathrm{K}^{+}$-ATPase $\beta$-subunit (red), aromatase (green), and their merged overlay of Wistar (A-C) and SD (D-F) rats. In both strain, aromatase co-localized with $\mathrm{H}^{+} / \mathrm{K}^{+}$-ATPase $\beta$-subunit in the parietal cells. Scale bars represent $10 \mu \mathrm{m}$.
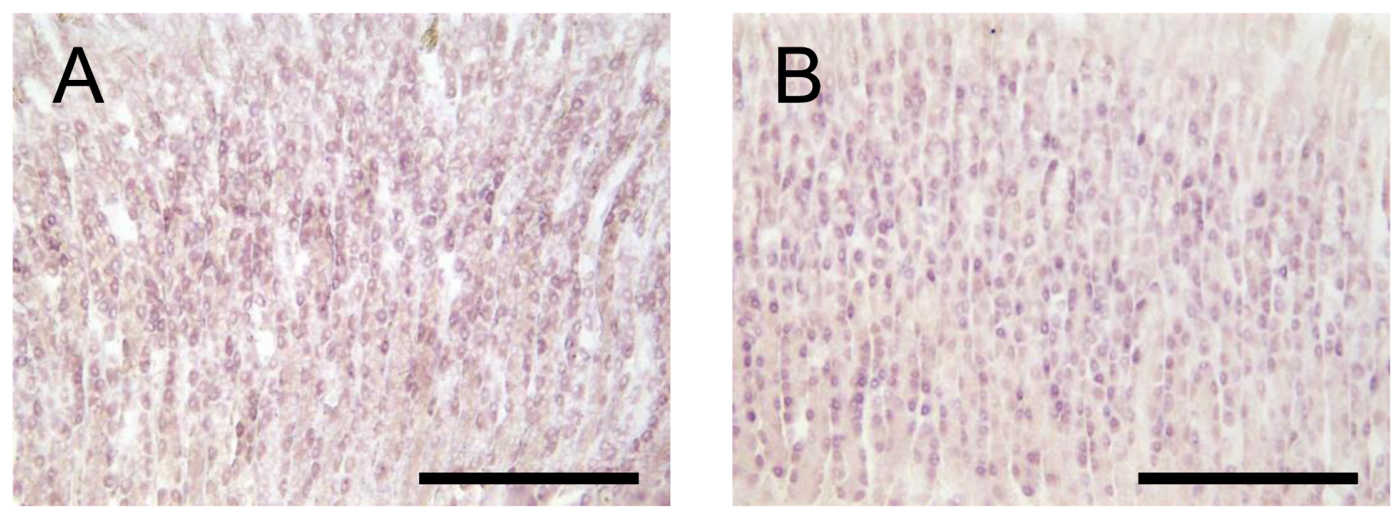

Fig. 3. Expression of Cyp19a1 mRNA in Wistar (A) and SD (B) rats. In situ hybridization signals are shown in red purple. Cyp19al were expressed in fundic glands of both strains. Scale bars represent $200 \mu \mathrm{m}$.

expressed in the gastric mucosa of SD rats as well as of Wistar rats (Fig. 3). This indicates that aromatase mRNA is translated in the parietal cells, but aromatase does not come from other tissues. Estrogens are synthesized in the parietal cells when testosterone or androstenedione is supplied as a substrate. We also confirmed that aromatase did not colocalize with pepsinogen and ghrelin (data not shown). This result suggests that only parietal cells in the stomach of SD rats synthesize and secrete estrogens. Therefore, SD rats were shown to be ideally suited for the study of gastric estrogens synthesis as well as Wistar rats. We consider that SD rats are useful for experiments that require surgeries and experiments that require large amounts of samples from one individual because they are larger than Wistar rats. Conversely, Wistar rats are known to be smaller and are known to have a high survival rate in long-term breeding experiments. Consequently, Wistar rats are useful for experiments that use lower amounts of drugs, aging or timedependent experiments, and experiments that require samples from many individuals.

In the gastric mucosa of SD rats, all steroid synthases to convert estrogens from progesterone were confirmed. Estrogen synthesis pathways in the parietal cells of Wistar and SD rats can be regarded as identical. Progesterone as the substrate of estrogens is converted from cho- 

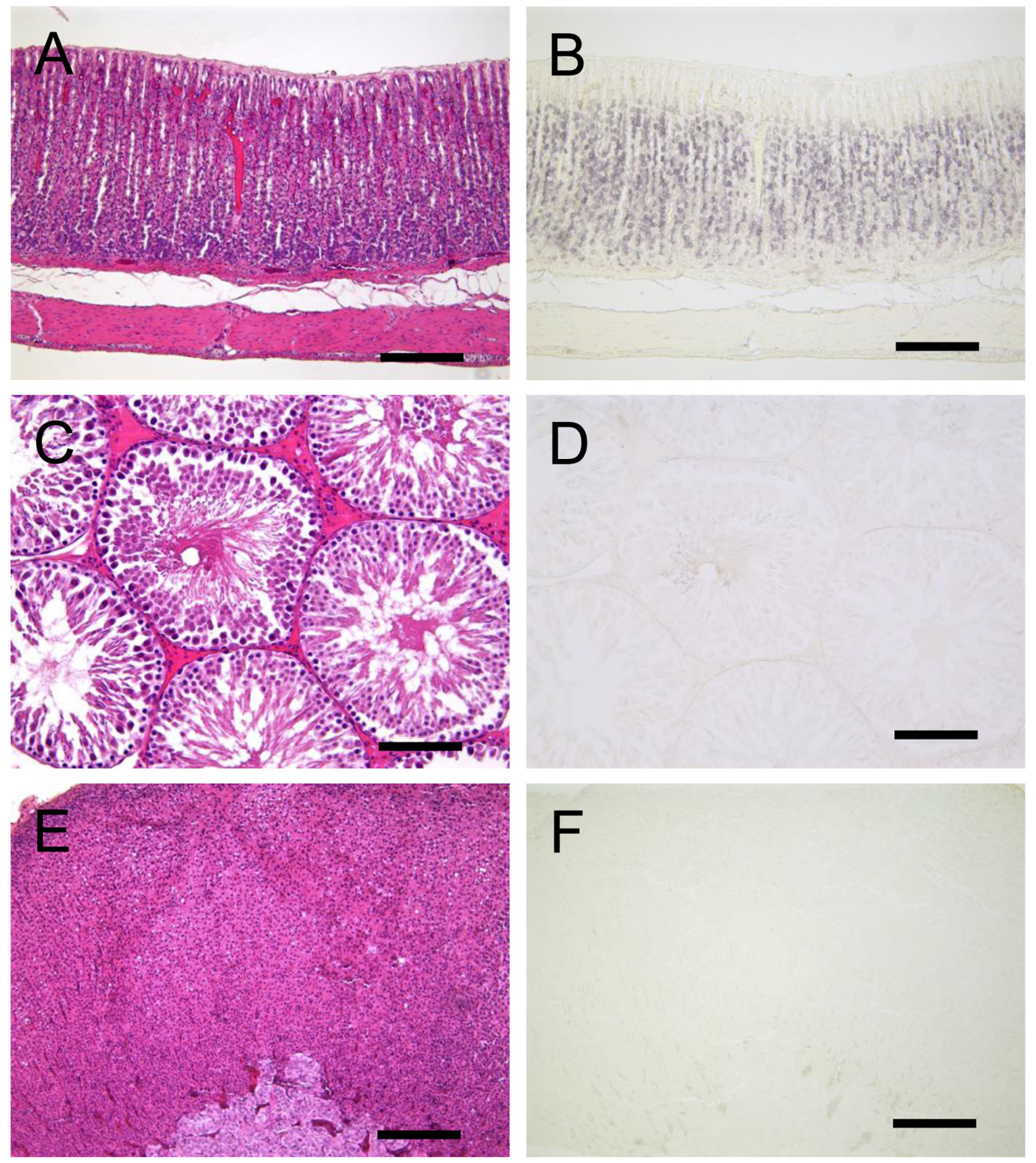

Fig. 4. Light photomicrographs obtained under the same conditions (HE staining - A, C, and E; immunohistochemistry of aromatase - B, D, and F) of the gastric mucosa (A and B), testis (C and D), and adrenal gland (E and F) are shown. No immunostained cells were found in the testis or adrenal gland, but the gastric mucosa has many aromatase positive cells. Scale bars represent $200 \mu \mathrm{m}$ in the stomach and adrenal gland, and $100 \mu \mathrm{m}$ in the testis.

lesterol by $\mathrm{P} 450$ cholesterol side-chain cleavage enzyme (P450scc) [32]. Actually, P450scc does not exist in the gastric mucosal epithelium [8]. Large amounts of P450scc are known to be expressed in all three zones of the adrenal cortex $[33,34]$, theca interna of the ovary [32], and Leydig cells in the testis [35]. Therefore, when the substrate level is increased or decreased because of these organ or steroidogenic abnormalities, it might affect gastric estrogen synthesis.

Although no significant difference of steroid synthase proteins was found (Fig. 6), differences were found between the respective mRNA expressions of Wistar and SD rats (Fig. 5). In mRNA expressions, $H s d 17 b 2$ mRNA expression in SD was less than in Wistar rats. Actually, 17 $\beta$-HSD type 2 translated from $H s d 17 b 2$ reverses testosterone to androstenedione in contradiction to steroidogenesis downstream. Conversely, other mRNAs in SD expressed more than Wistar rats. Although no significant difference was found, these tendencies are reflected in protein levels and serum hormone levels in the portal vein. Particularly, Srd5al was expressed much higher. Therefore, SD rats tend to have a more dominant pathway for converting testosterone to dihydrotestosterone rather than E2 compared to the pathway for Wistar rats. These results suggest possible differences in the hormone synthesis in the stomach depending on the strain. 


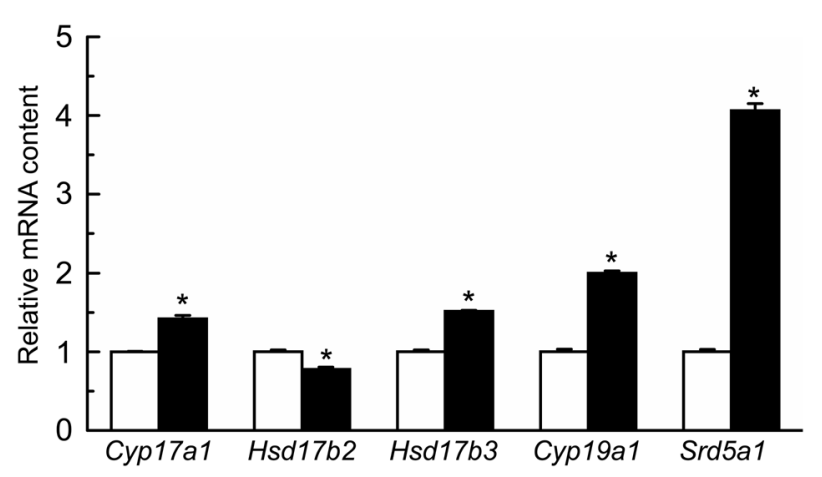

Fig. 5. Gene expression of steroidogenic enzymes in the gastric mucosa. Compared with the expression of Wistar rats, Cyp17a1, Hsd17b3, Cyp19al, and Srd5al mRNA are markedly higher. Especially, Srd5al mRNA expression in SD rats is about four times higher than Wistar. However, Hsd17b2 mRNA expression is lower than Wistar rats. White column indicates Wistar rats, and black one is SD rats. Each column shows the mean. The bar represents the standard error of data for four animals in each group. $* P<0.05$ vs. Wistar rats.

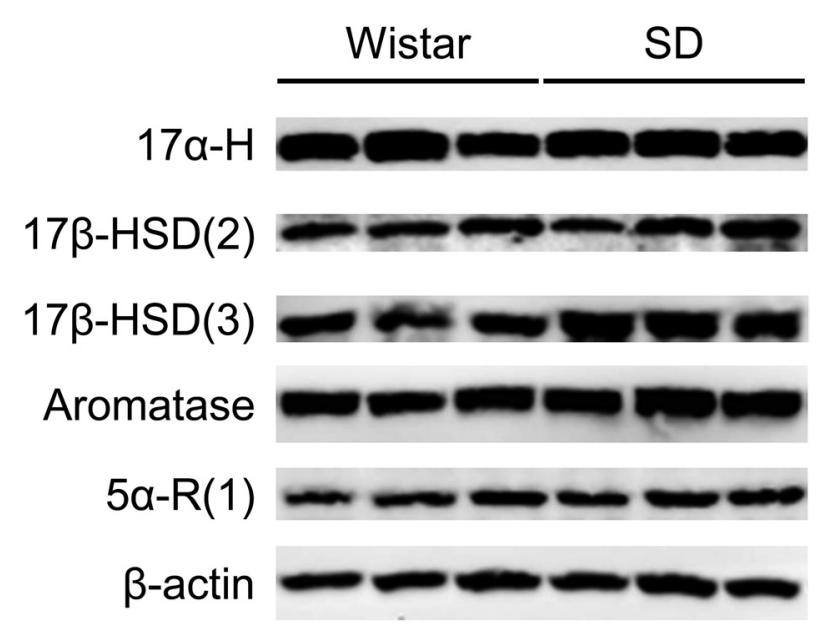

Fig. 6. Lysates of gastric mucosa were loaded on an SDS-PAGE, and $17 \alpha-H, 17 \beta-H S D(2), 17 \beta-H S D(3)$, aromatase, and $\beta$-actin were detected by immunoblotting. No difference was found in the concentrations of steroidogenic enzyme proteins.

Table 2. Serum steroid hormone concentrations

\begin{tabular}{lcccccc}
\hline & $\begin{array}{c}\text { Progesterone } \\
(\mathrm{ng} / \mathrm{mL})\end{array}$ & $\begin{array}{c}\text { Androstenedione } \\
(\mathrm{pg} / \mathrm{mL})\end{array}$ & $\begin{array}{c}\text { Testosterone } \\
(\mathrm{ng} / \mathrm{mL})\end{array}$ & $\begin{array}{c}\text { Dihydrotestosterone } \\
(\mathrm{pg} / \mathrm{mL})\end{array}$ & $\begin{array}{c}\text { Estrone } \\
(\mathrm{pg} / \mathrm{mL})\end{array}$ & $\begin{array}{c}\text { 17/-estradiol } \\
(\mathrm{pg} / \mathrm{mL})\end{array}$ \\
\hline Wistar & $1.23 \pm 0.23$ & $165.25 \pm 23.29$ & $2.06 \pm 0.30$ & $38.58 \pm 6.38$ & $4.06 \pm 1.18$ & $57.01 \pm 9.99$ \\
SD & $1.35 \pm 0.26$ & $218.20 \pm 31.24$ & $3.32 \pm 0.84$ & $61.77 \pm 17.37$ & $3.60 \pm 0.63$ & $32.21 \pm 7.46$ \\
\hline
\end{tabular}

$\mathrm{n}=7$, Mean \pm SEM.

Dihydrotestosterone, an endogenous androgen sex steroid and hormone, is converted from testosterone by $5 \alpha$-reductase type 1 . Actually, $5 \alpha$-reductase type 1 is expressed in more locations, including the liver, skin, scalp and prostate. These organs synthesize dihydrotestosterone [36]. Dihydrotestosterone synthesized in the stomach flows into the portal vein, where it is metabolized in the liver as well as estrogens. Reportedly, glucocorticoids and androgens differentially regulate $\operatorname{Srd} 5 \mathrm{a} 1 \mathrm{mRNA}$ in the rat liver [37]. Consequently, the possibility exists that dihydrotestosterone synthesized in the stomach is involved in steroid metabolism in the liver.

Aromatase is well known to be expressed mainly in granulosa cells of the ovary. Furthermore, earlier reports show that aromatase is expressed in various organs [1-6]. Especially, the testes and adrenal glands are well known as estrogen-producing organs other than the ovary. However, aromatase protein levels in these organs were significantly lower, as portrayed in Fig. 4. In Wistar rats, the mRNA level in the testis was about $10^{-2}$ times and the adrenal gland was about $10^{-5}$ times lower compared to the gastric mucosa [38]. Result of SD rats of the mRNA level is almost identical to that obtained for the Wistar rats (data not shown). With increased sensitivity, aromatase will be detected in the testis and adrenal gland.
However, aromatase levels are clearly expressed in gastric mucosa and are much higher than in these organs. Although this study does not investigate ovarian aromatase in SD rats, we presume that comparison with ovarian aromatase shows the same tendency as that found for Wistar rats [39].

We have been researching the stomach as a new organ producing estrogens [10, 12-14, 38-41]. Aromatasepositive parietal cells were costained with the $\mathrm{H}^{+} / \mathrm{K}^{+}$ATPase $\beta$-subunit completely (Fig. 2). Consequently, the cells which express aromatase are parietal cells. However, the opposite situation is not always the same. In postnatal development, aromatase starts to express in the gastric mucosa from 20 days after birth [13]. However, $\mathrm{H}^{+} / \mathrm{K}^{+}$-ATPase $\beta$-subunit was expressed in the gastric mucosa at 0 day after birth. Also, in adult rats, $\mathrm{H}^{+} / \mathrm{K}^{+}$ATPase $\beta$-subunit doesn't necessarily colocalize with aromatase in the parietal cells [38]. We believe that further research is necessary on the developmental process of parietal cells. Moreover, the regulation mechanism and existence significance of gastric estrogens synthesis remain unknown. We regard this phenomenon as clinically important. Therefore, extensive research using SD as well as Wistar rats must be undertaken in future studies. 


\section{Conflicts of Interests}

The authors declare that they have no conflict of interest that would prejudice the impartiality of this research work.

\section{Funding}

Funding from the Annual Plan of Yamagata University (grant number DAY2609) is gratefully acknowledged.

\section{Acknowledgments}

We are deeply grateful to laboratory members for giving us constructive comments and warm encouragement.

\section{References}

1. Baird DT, Horton R, Longcope C, Tait JF. Steroid dynamics under steady-state conditions. Recent Prog Horm Res. 1969; 25: 611-664. [Medline]

2. de Jong FH, Hey AH, van der Molen HJ. Oestradiol-17 beta and testosterone in rat testis tissue: effect of gonadotrophins, localization and production in vitro. J Endocrinol. 1974; 60: 409-419. [Medline] [CrossRef]

3. Dorrington JH, Armstrong DT. Follicle-stimulating hormone stimulates estradiol-17 $\beta$ synthesis in cultured Sertoli cells. Proc Natl Acad Sci USA. 1975; 72: 2677-2681. [Medline] [CrossRef]

4. Erickson GF, Hsueh AJW. Stimulation of aromatase activity by follicle stimulating hormone in rat granulosa cells in vivo and in vitro. Endocrinology. 1978; 102: 1275-1282. [Medline] [CrossRef]

5. Fukuda S, Terakawa N, Sato B, Imori T, Matsumoto K. Hormonal regulation of activities of $17 \beta$-ol-dehydrogenases, aromatase and 4-ene- $5 \alpha$-reductase in immature rat ovaries. J Steroid Biochem. 1979; 11: 1421-1427. [Medline] [CrossRef]

6. Weisz J, Gunsalus P. Estrogen levels in immature female rats: true or spurious--ovarian or adrenal? Endocrinology. 1973; 93: 1057-1065. [Medline] [CrossRef]

7. Ueyama T, Shirasawa N, Ito T, Tsuruo Y. Estrogen-producing steroidogenic pathways in parietal cells of the rat gastric mucosa. Life Sci. 2004; 74: 2327-2337. [Medline] [CrossRef]

8. Ueyama T, Shirasawa N, Numazawa M, Yamada K, Shelangouski $\mathrm{M}$, Ito T, et al. Gastric parietal cells: potent endocrine role in secreting estrogen as a possible regulator of gastro-hepatic axis. Endocrinology. 2002; 143: 3162-3170. [Medline] [CrossRef]

9. Mohibbi H, Qasimi MI, Nagaoka K, Watanabe G. Steroidogenic enzyme expression in estrogen production in the goat gastrointestinal (GI) tract and the effect of castration. J Vet Med Sci. 2017; 79: 1253-1260. [Medline] [CrossRef]

10. Kobayashi H, Yoshida S, Shirasawa N, Maeda K, Naito A. Expression and localization of aromatase in human gastric mucosa : Immunohistochemical study using biopsy materials. Histochem Cell Biol. 2019; 151: 21-28. [Medline] [CrossRef]

11. Dickson G. Gynecomastia. Am Fam Physician. 2012; 85: 716-722. [Medline]

12. Kobayashi H, Yoshida S, Sun YJ, Shirasawa N, Naito A. Gastric estrogen increases pituitary estrogen receptor $\alpha$ and prolactin mRNAs during the different pathological conditions of the liver. Endocrine. 2013; 43: 170-183. [Medline] [Cross-
Ref]

13. Kobayashi H, Yoshida S, Sun YJ, Shirasawa N, Naito A. Postnatal development of gastric aromatase and portal venous estradiol-17ß levels in male rats. J Endocrinol. 2013; 218: 117-124. [Medline] [CrossRef]

14. Kobayashi H, Yoshida S, Sun YJ, Shirasawa N, Naito A. Gastric $17 \beta$-estradiol in portal vein and liver Esr1 make a circadian rhythm in systemic circulation in male rats. Endocrine. 2016; 53: 565-573. [Medline] [CrossRef]

15. Morii S, Fujii T. [Spontaneous tumors in Sprague-Dawley JCL rats (author's transl)]. Jikken Dobutsu. 1973; 22: 127-138. (in Japanese) [Medline]

16. Okada M, Takeuchi J, Sobue M, Kataoka K, Inagaki Y, Shigemura M, et al. Characteristics of 106 spontaneous mammary tumours appearing in Sprague-Dawley female rats. Br J Cancer. 1981; 43: 689-695. [Medline] [CrossRef]

17. Prejean JD, Peckham JC, Casey AE, Griswold DP, Weisburger EK, Weisburger JH. Spontaneous tumors in Sprague-Dawley rats and Swiss mice. Cancer Res. 1973; 33: 2768-2773. [Medline]

18. Stone JP, Holtzman S, Shellabarger CJ. Neoplastic responses and correlated plasma prolactin levels in diethylstilbestroltreated ACI and Sprague-Dawley rats. Cancer Res. 1979; 39: 773-778. [Medline]

19. Takabatake M, Daino K, Imaoka T, Blyth BJ, Kokubo T, Nishimura $Y$, et al. Differential effect of parity on rat mammary carcinogenesis after pre- or post-pubertal exposure to radiation. Sci Rep. 2018; 8: 14325. [Medline] [CrossRef]

20. Thompson SW, Huseby RA, Fox MA, Davis CL, Hunt RD. Spontaneous tumors in the Sprague-Dawley rat. J Natl Cancer Inst. 1961; 27: 1037-1057. [Medline]

21. Young S, Cowan DM. Spontaneous regression of induced mammary tumours in rats. Br J Cancer. 1963; 17: 85-89. [Medline] [CrossRef]

22. Young S, Cowan DM, Davidson C. The production of mammary carcinomas in rats by 9,10-dimethyl-1,2-benzanthracene and its relationship to the oestrous cycle. Br J Cancer. 1970; 24: 328-332. [Medline] [CrossRef]

23. Diel P, Schmidt S, Vollmer G, Janning P, Upmeier A, Michna $\mathrm{H}$, et al. Comparative responses of three rat strains (DA/Han, Sprague-Dawley and Wistar) to treatment with environmental estrogens. Arch Toxicol. 2004; 78: 183-193. [Medline] [CrossRef]

24. Geis RB, Diel P, Degen GH, Vollmer G. Effects of genistein on the expression of hepatic genes in two rat strains (SpragueDawley and Wistar). Toxicol Lett. 2005; 157: 21-29. [Medline] [CrossRef]

25. Lawson DM, Sensui N, Gala RR. Ovariectomized SpragueDawley and Long-Evans rats release prolactin differently in response to estrogen. Life Sci. 1984; 34: 455-459. [Medline] [CrossRef]

26. McKim JM Jr, Wilga PC, Breslin WJ, Plotzke KP, Gallavan RH, Meeks RG. Potential estrogenic and antiestrogenic activity of the cyclic siloxane octamethylcyclotetrasiloxane (D4) and the linear siloxane hexamethyldisiloxane (HMDS) in immature rats using the uterotrophic assay. Toxicol Sci. 2001; 63: 37-46. [Medline] [CrossRef]

27. Mitsui T, Ishida M, Izawa M, Arita J. Differences between rat strains in the development of PRL-secreting pituitary tumors with long-term estrogen treatment: In vitro insulin-like growth factor-1-induced lactotroph proliferation and gene expression are affected in Wistar-Kyoto rats with low estrogen-susceptibility. Endocr J. 2013; 60: 1251-1259. [Medline] [CrossRef]

28. Nelson DR, Koymans L, Kamataki T, Stegeman JJ, Feyereisen R, Waxman DJ, et al. P450 superfamily: update on new sequences, gene mapping, accession numbers and nomenclature. Pharmacogenetics. 1996; 6: 1-42. [Medline] [CrossRef]

29. Livak KJ, Schmittgen TD. Analysis of relative gene expression data using real-time quantitative PCR and the 2(-Delta Delta C(T)) Method. Methods. 2001; 25: 402-408. [Medline] 
[CrossRef]

30. Ikeda K, Shiraishi K, Yoshida A, Shinchi Y, Sanada M, Motooka Y, et al. Synchronous Multiple Lung Adenocarcinomas: Estrogen Concentration in Peripheral Lung. PLoS One. 2016; 11: e0160910. [Medline] [CrossRef]

31. Ando T, Nishiyama T, Takizawa I, Miyashiro Y, Hara N, Tomita Y. A carbon 21 steroidal metabolite from progestin, $20 \beta$-hydroxy- $5 \alpha$-dihydroprogesterone, stimulates the androgen receptor in prostate cancer cells. Prostate. 2018; 78: 222-232. [Medline] [CrossRef]

32. Hanukoglu I. Steroidogenic enzymes: structure, function, and role in regulation of steroid hormone biosynthesis. J Steroid Biochem Mol Biol. 1992; 43: 779-804. [Medline] [CrossRef]

33. Geuze HJ, Slot JW, Yanagibashi K, McCracken JA, Schwartz $\mathrm{AL}$, Hall PF. Immunogold cytochemistry of cytochromes $\mathrm{P}-450$ in porcine adrenal cortex. Two enzymes (side-chain cleavage and 11 beta-hydroxylase) are co-localized in the same mitochondria. Histochemistry. 1987; 86: 551-557. [Medline] [CrossRef]

34. Mitani F, Shimizu T, Ueno R, Ishimura Y, Izumi S, Komatsu $\mathrm{N}$, et al. Cytochrome P-45011 beta and P-450sce in adrenal cortex: zonal distribution and intramitochondrial localization by the horseradish peroxidase-labeled antibody method. J Histochem Cytochem. 1982; 30: 1066-1074. [Medline] [CrossRef]

35. Payne AH. Hormonal regulation of cytochrome P450 en- zymes, cholesterol side-chain cleavage and 17 alpha-hydroxylase/C17-20 lyase in Leydig cells. Biol Reprod. 1990; 42: 399-404. [Medline] [CrossRef]

36. Azzouni F, Godoy A, Li Y, Mohler J. The 5 alpha-reductase isozyme family: a review of basic biology and their role in human diseases. Adv Urol. 2012; 2012: 530121. [Medline] [CrossRef]

37. El-Awady MK, El-Garf W, El-Houssieny L. Steroid 5alpha reductase mRNA type 1 is differentially regulated by androgens and glucocorticoids in the rat liver. Endocr J. 2004; 51: 37-46. [Medline] [CrossRef]

38. Kobayashi H. Estrogen synthesis in gastric parietal cells and secretion into portal vein. Anat Sci Int. 2020; 95: 22-30. [Medline] [CrossRef]

39. Kobayashi H, Yoshida S, Sun YJ, Shirasawa N, Naito A. Changes of gastric aromatase and portal venous $17 \beta$-estradiol during the postnatal development and estrus cycle in female rats. Endocrine. 2014; 46: 605-614. [Medline] [CrossRef]

40. Kobayashi H, Yoshida S, Sun YJ, Shirasawa N, Naito A. Gastric estradiol-17 $\beta\left(\mathrm{E}_{2}\right)$ and liver $\mathrm{ER} \alpha$ correlate with serum $\mathrm{E}_{2}$ in the cholestatic male rat. J Endocrinol. 2013; 219: 39-49. [Medline] [CrossRef]

41. Kobayashi H, Yoshida S, Sun YJ, Shirasawa N, Naito A. $17 \beta$-Estradiol in the systemic circulation derives mainly from the parietal cells in cholestatic female rats. J Endocrinol Invest. 2016; 39: 389-400. [Medline] [CrossRef] 